\title{
НАСЛЕДИЕ
}

И ТРАНСФОРМАЦИИ

\section{Kapa X.}

\section{ИНСТИТУЦИОНААЬНЫЕ ОСОБЕННОСТИ БААГОТВОРИТЕАЬНОСТИ В ТУРЦИИ}

\begin{abstract}
Аннотация. В статье анализируется институт социальной взаимопомощи - вакфы. Автор рассматривает пример туреиких вакфов. Предметом статьи явялется история развития вакуфной системь в Турции. Объектом статьи служат турецкие вакфы. Автор подробно рассматривает виды и функции вакфов, а также уделяет внимание правовой стороне вопроса. Также автор описывает, как ступенчато эволючионировала вакуфнал система стечением времени и под влиянием меняющихся политических и социально-экономических условий. Особое внимание автор уделяет видам сочиальной помощи, которую вакфы исторически предоставляли нуждающимся. В качестве методологии автор использует компаративистику, сравнивал развитие вакуфной системы в Османской империи и в современной Турции, а также принцип историзма, прослеживая возникновение и развитие анализируемых явлений с учетом конкретной исторической ситуачии. В заключении статьи автор приходит к следующим выводам. Если в Османской империи вакфы были, прежде всего, религиозным институтом, то с распадом империи и с приходом к власти начионалистов во главе с Мустафой Кемалем Ататюрком, начинаются процессы секуляризачии вакуфной системы. С принятием в 1967 году нового законодательства деятельность вакфов переходит в коммерческое русло. С течением времени больиинство вакфов утратили свой религиозный характер. На новейшем этапе истории вакфы становлттся своего рода рычагами социальной мобилизачии и средством реализации гражданской активности. Научная новизна исследования заключается, главным образом, в том, что тема благотворительности в мусульманских обществах является очень слабо изученной в российской историографии. Статья может быть интересна для историков, сочиологов, а также для специалистов, изучающиих Туриию и Ближний Восток.
\end{abstract}

Кнючевые слова: сочиальная помощь, финантропия, благотворительность, вакуфнал система, вакуфное имущество, вакуфный сектор, вакфы, Турция, Османская империя, Ислам. 


\section{ПОАИТИКА И ОБЩЕСТВО • 6 (138) • 2016}

Abstract. This article analyzes the institution of mutual aid - waqf. The author examines the example of the Turkish waqfs. The subject of the research is the history of development of the waqf system in Turkey, while the object is the Turkish waqfs. The author thoroughly examines the types and functions of the waqfs, and gives special attention to the legal aspect of the question. He also describes the gradual evolution of the waqf system within time and under the influence of the changing political and socioeconomic conditions. A peculiar attention is also given to the types of social aid, which the waqfs historically provide to people in need. As the methodological base the author uses the comparative method for comparing the waqf system in the Ottoman Empire and in the modern Turkey, as well as the principle of historicism for tracking the emergence and development of the analyzing phenomena with consideration of a specific historical situation. If in the Ottoman Empire, the waqfs were primarily the religious institutions, then with the collapse of the Empire and with the arrival of nationalists to power led by Mustafa Kemal Atatürk, we can observe the processes of secularization of the waqf system. With the codification of the new legislation in 1967, the activity of waqfs takes on commercial character. And within time, the majority of waqfs have lost their religious nature. On the new stage of historical development, the waqfs in its own way become the triggers of the social mobilization and the means of realization of civil activity. The scientific novelty consists in the fact that the topic of charity in the Muslim societies is very little-studied within the Russian historiography. This article can be interesting for the historians, sociologists, as well as specialists majoring Turkey and Near East.

Key words: Turkey, social aid, philanthropy, charity, waqf system, waqf property, waqf sector, waqfs, Ottoman Empire, Islam.

\section{Часть 1. История созАания и кмассификация вакфов}

В законодательстве мусульманских государств (фикхе) термин «вакф» обозначает неотчужАаемое имущество, которое Аобровольно было передано на религиозные или благотворительные цели общине, организации или отдельному человеку [1, с. 12]. В Исламе понятие вакфа используется Аля обозначения вмадения опредеменной собственностью и сохранения ее с целью благотворительности или иной общественной пользы. Цель использования вакфа четко оговаривается при его созАании в специальном вакуфном Аоговоре. В вакуфном договоре три стороны: учредитель (вакиф), управмяющий (мутавамли) и бенефициарий (маукуф 'амайхи). Исторически мутавамли был кмючевой фигурой в вакуфном Аоговоре. От эффективности управленческой Аеятельности мутавамли напрямую зависела судьба и состояние вакфа. Ввакуфном договоре обычно опредемялся размер жалования управмяющего. Как правило, сумма составцяла $10 \%$ от общего Аохода, получаемого с вакуфного имущества. В редких скучаях в договоре указывалась фиксированная сумма. В обязанности мутавалми входило управление вакуфным имуществом в интересах бенефициариев. Последние назначались учредителем вакфа (вакифом). Чаще всего бенефициариями (выгодоприобретателями), согласно вакуфному договору, являлись мечети. Также бенефициариями могли выступать образовательные учреждения, больницы, усыпальницы, бесплатные столовые или же бедные и нужАающиеся люди [2, с. 108].

Учредитель вправе передать в вакф только то имущество, собственником которого сам явмяется. Исключением служат так называемые «неправильные вакфы» или «вакфы султана». В этом случае учредителем вакфа выступал султан, который превращал в вакф земли, принаАлежавшие казне [2, с. 107].

Имущество, которое перешло в вакф, утрачивает свойства собственности: вакуфное имущество нельзя ни продать, ни подарить, ни наследовать. ЗАесь и раскрывается суть термина «вакф», которое, переводится с арабского как «остановка» или «задержка». Имущество, переданное в вакф, с одной стороны, перестает быть собственностью учредителя вакфа. С 
Аругой стороны, оно и не становится собственностью тех, в пользу кого это имущество было передано.

Вакф является не только религиозным или правовым институтом, Помимо всего прочего, вакуфное имущество играет роль важной социально-экономической категории.

Независимо от толкований размичных мусульманских правоведов, вакф Аолжен отвечать следующим нескольким критериям:

1. Вакф - это бессрочное, безотзывное и неотчужАаемое имущество. Учредитель вакфа не может отменить своего решения о его создании;

2. Предмет вакфа должен реально существовать: нематериальные вещи не могут стать вакуфным имуществом;

3. Вакф Аолжен приносить мибо пользу, мибо АохоА. Но в то же время, он не может быть расходуемым. Иными словами, в вакуфное имущество неАопустимо переводить еАу, напитки или оАеЖАу;

4. Вакуфное имущество может быть как Авижимым, так и неАвижимым;

5. Вакф недопустимо использовать на непозволительные с точки зрения мусульманской этики цели;

6. Имущество может быть объявлено вакфом как в письменной, так и в устной форме;

7. Запрещается создавать вакф в пользу состоятельных мюдей, так как он призван служить на благотворительные нужды [2, с. 107].

В зависимости от заАач, которые преследоваиись при их учреждении, вакфы подразделяются на семейные (потомственные) и благотворительные. Существуют также и поделенные вакфы - наполовину семейные, наполовину бкаготворительные.

В случае чисто благотворительных вакфов его учреАителю не оставалось никакого дохода с его коммерческих объектов. Семейные вакфы, напротив, созАавались Аля поААержки Потомков его учредителя. Поделенные вакфы, которые сочетали в себе характеристики и семейных, и благотворительных вакфов.

Как отмечает российский исследователь П.В. ШАыков в своей монографии, посвящен- ной вакфам, на первый взгляА может показаться, что семейные вакфы противоречат принципу «скужения на благо общества». Тем не менее, толкователи мусульманского права не видят в феномене семейных вакфов никаких противоречий. Аело в том, что с точки зрения ислама благотворительность начинается именно с семьи и Аома, поскольку семья и Аом явцяются основой общества, а следовательно, семейный вакф по своей сути ничем не отличается от благотворительного учрежАения [1, с. 36].

В подтвержАение подобной трактовки толкователи ислама приводили слова, которые приписываются пророку МухаммеАу: «Иучше оставить семью в достатке, чем в нужАе... » [3, p. 1176]. Или же такое высказывание пророка: «семья и потомки - поАХоАящий объект Амя благотворительности ... отАавать среАства Аля их будущей жизни - более благородно и благочестиво, нежели отАавать что-либо нищему незнакомцу» [3, p. 1176].

Исторически первые Ава вакфа были учрежАены самим пророком Мухаммедом: один из них носил религиозный характер (вакф хайри), Аругой - гражАанский (вакф 'амм).

Первый вакф имел религиозное назначение. С целью возведения мечети Пророк приобрел землю в селении Куба под Мединой. Строительство первой мечети бымо закончено в 622 году от рождества Христова. Она существует и по сей день на том же месте. Кроме того, МухаммеА первым учредил вакф в пользу нуждающихся членов мусульманской общины. Вакф включам в себя семь фруктовых садов, которые Мухаммеду завещал один из жителей Медины [2, с. 106].

После смерти Пророка большинство его сподвижников последовали его примеру и выступили учредителями тех или иных вакфов. Покучив широкое распространение, вакфы стали УАовлетворять широкий спектр индивидуальных, групповых и государственных потребностей. Исторически вакфы оказывали большое влияние на социальное развитие мусульманского мира и принимами на себя часть функций государства.

На протяжении многих веков вакфы быми еАинственным постоянным источником финансирования высшего образования в мусульман- 


\section{ПОАИТИКА И ОБЩЕСТВО • 6 (138) • 2016}

ском обществе. В этом скучае средства, полученные с вакуфного имущества, передавались не только преподавателям и на содержание учебного заведения, но и обскуживающему персонаму: поварам, посудомойкам, сторожам и так дамее. Вакфы и по сей день явмяются важнейшим источником финансирования образования во многих мусульманских странах.

\section{Часть 2. Вакфы в социальной системе Османской империи}

В Османской империи система вакфов межала в основе экономики и социального порядка госуАарства. Особое значение в турецкой вакуфной системе имели так называемые «имперские вакфы» [4], которые создавались самими правителями или членами их семей, а также высокопоставленными государственными служащими (визирями и генерал-губернаторами). Имперские вакфы содержали обширные сельскохозяйственные земли, а также зАания. АохоА от таких вакфов направлялся на социальные и образовательные нужды, а также в пользу мечетей. Вакфы брали на себя функцию перераспределения Аоходов. Они получали доход с сельскохозяйственных земель и перераспредемяли его в пользу городской экономики. Например, Аля обскуживания мечети Сулеймание в Стамбуле ими мечети Баезида II, расположенной в городе Амасья, перераспределялся дохоА, полученный с сотен деревень [4]. Сами по себе эти мечети также были частью вакфов. Так называемые вакуфные комплексы включали в себя, с оАной стороны, мечети, библиотеки, бесплатные столовые, шкомы, университеты, то есть размичного рода учрежАения, требовавшие среАств Аля своего содержания. С Аругой стороны, вакуфное имущество охватывало разнообразные сельскохозяйственные угодья, технику, зАания, с которых получами АохоА, направмяемый Аалее на благотворительные цели.

Вакфы обеспечивали занятость Амя квалифицированной и неквалифицированной рабочей симы. К примеру, обширный вакуфный компмекс Сумеймание в Стамбуле обеспечивац занятость более чем 700 человек. Таким образом, если считать рабочих вместе с их семьями, то в общей со- вокупности крупные вакфы могли обеспечивать проживание тысячам граждан [4].

Традиционно имперские вакфы в Османской империи занимались обеспечением образования. Они строили обще образовательные шкомы, средние школы (медресе), а также снабжали учрежАения высшего образования. Например, вакуфный комплекс Сумеймание включал в себя начальную школу, школу Аля медиков, а также пять учреждений, предоставцявших высшее образование.

В Османской империи вакфы формировали развернутую систему разнообразной социальной помощи и функционировали как механизм снижения уровня бедности в обществе. Практически каждый вакуфный комплекс имел свою бесплатную столовую (имарет), которая предоставляла еАу работникам вакфа и обеспечивала питанием беднякови нужАающихся. Вакфы социальной помощи выплачивали пособия нужАающимся, раздавали одежАу сиротам и беАным, Аавали приют вдовам. С вакуфных доходов преАоставлялась материальная подАержка сиротам вплоть Ао Аостижения ими совершеннолетия. Вакфы также могли заниматься замужеством небогатых девушек и вАов, оплачивать им расходы на свадьбу. Порой социальная помощь, оказываемая вакфами, носила весьма специфический характер: они могли оплачивать Аолги попавших в тюрьму заключенных, а также способствовать их освобожАению.

Аолгие годы вакфы служили механизмом налаживания контактов межАу властью и насемением. Исторически вакфы были среАством подАержания общего достатка и благополучия в государстве. В этом случае имела место так называемая «вертикальная» социальная помощь, когАа общество в Аице своих институтов или ОтАеАьнЫХ ИНАИвИАОВ Аелится Своими благами с наиболее слабыми и нужАающимися $[1$, с. 49]. Вертикальной такая помощь называется в силу того, что она пересекает границы социальных слоев и тем самым объединяет их межАу собой. Таким образом, этот виА бкаготворительности, помимо всего прочего, быи и среАством консомидации общества.

Важное значение среди вакуфных учреждений имели так называемые завие. Последние 
объеАиняли в своей структуре школы, молемьные комнаты и приюты Аля нищих. Завие собирами одновременно путешественников, бедняков и просто жителей окрестностей. Как отмечает турецкий исследователь Назиф Озтюрк (Nazif Ozturk), в условиях, когда средства коммуникации были крайне слабо развиты, завие выступали одним из главных механизмов взаимодействия межАу различными социальными слоями и группами. Они также вносили существенный вклад в подАержание социальной солидарности и социального равновесия [5, s. 43].

Вообще вакфы традиционно выступали важнейшим фактором социальной политики. С оАной стороны, они осуществляли благотворительные функции, с Аругой стороны - облаАали социально-интегративными свойствами. В первом скучае мы говорим обо всем обширном комплексе Аеятельности вакфов в области культуры, строительства, организации гороАской инфраструктуры, помощи бедным и т.А. Во втором случае имеется в виду нацеленность вакфов на объединение мюдей из разных социальных слоев, а также на сглаживание социальных размичий и снижение уровня социальной напряженности. ЗАесь также стоит упомянуть, что вакфы исторически выступали механизмом, при помощи которого госуАарство стремилось заслужить симпатию населения на неАавно завоеванных территориях. Кроме того, вакфы принимали активное участие в культурном преображении новых территорий. При помощи вакуфных доходов преображалась архитектура завоеванных городов («исламизировакась»). Они также создавали более благоприятные условия Аля проживания, что позвомямо кочевникам приобщиться к городской культуре. Таким образом, благодаря деятельности османских социальных институтов, завоеванные города становились похожими на мусульманские и превращались в крупные культурные центры.

Наибольшее развитие среди учреждений, создаваемых на основе вакфов, в Османской империи получили благотворительные комплексы кюммие. Они являются историческим аналогом современных социальных скужб. Как правило, их строили правители, чкены их семей или просто зажиточные мюди с целью осуществления бла- готворительной Аеятельности. Кюмлие преАставляли собой обширные вакуфные комплексы, который включали в себя мечеть и примыкавшие к ней зАания (мечети, больницы, библиотеки, бани и т. А.). ИногАа в центре кюммие вместо мечети располаганось меАресе.

Помимо перечисленных учреждений, кюллие могли включать в себя начальные школы, приюты, благотворительные столовые, кладбища, рынки, гостиницы, караван-сараи, источники чистой питьевой воды, фонтаны, меАресе, гробницы, фонтаны, молельные комнаты и Аругое.

Кюмлие служили центральным элементом городской архитектуры в Османской империи. Самое широкое распространение они получили как раз в эпоху расцвета империи (примерно с XI века н. э.). В кюлмие возводился мавзолей Аля учредителя вакфа (вакифа), а также обустраивался саА, который позже использовали как кладбище, гАе хоронили служащих вакфа, а также членов семей вакифа.

Кюмлие имели и просветительскую функцию: посреаством медресе (учебных заведений) повышался обще образовательный уровень населения, в том числе и на недавно завоеванных территориях. ОАнако, как отмечает иссиедователь Назиф Озтюрк, главной функцией кюмлие все же бымо подаержание в обществе «чувства мусульманской солидарности и сплоченности» [5, s. 148].

Чтобы оценить масштабность значения вакфов Аля экономического развития городов и государства в целом, можно привести пример кюмлие Мехмеда Фатиха в Стамбуле. На содержание этой кюмлие в вакф бымо обращено 1130 Аомов, 4250 мавок, 3 постоялых дома, 4 хаммама, 7 башен, 9 садов и 118 обменных мавок, которые составмяли целую систему крытых рынков [6, s. 290].

Расцвет вакуфной системы в Османской империи начинается в XI веке. B XV - XVI веках они уже трансформировались в развитую систему благотворительных и религиозных учреждений.

ОАнако постепенно эффективность Аеятельности вакуфной системы снижалась. Это было вызвано как объективными, так и субъективными (внутренними) причинами. Среди субъ- 


\section{ПОАИТИКА И ОБЩЕСТВО • 6 (138) • 2016}

ективных причин можно назвать коррупцию внутри самих вакфов, а также кризис управмяемости. Объективным фактором выступац общий экономический кризис в империи: в конце XVI века наблюАается резкий рост инфмяции на фоне «революции цен» в Европе и так называемой «порчи монет». ПоА «порчей монет» подразумевается уменьшение содержания Арагоценных метаммов в монетах при сохранении их прежней номинацьной стоимости. Поскольку развитие экономики в те времена шло незначительными темпами, все эти негативные факторы усугубцямись постепенно.

К XIX веку кризис вакуфной системы в империи Аостигает своего пика. Многие критики говорими о крайне негативном влиянии вакфов на экономическую, социамьную, а также Ауховную и кумьтурную стороны жизни османского общества [1, с. 56]. Согласно их мнению, вакфы способствовали общему разможению османского общества. Критики обращали внимание на то, что вакфы не устраняют, а поощряют беАность, в частности, через организацию бесплатных столовых и предоставление нищим социальной помощи. Также вакфы способствовали формированию целого слоя бенефициаров социальной помощи, что привоАило к искАючению множества $ю$ юей из активной произвоАительной Аеятельности, нанося серьезный урон экономике государства.

Вакуфная система критиковалась еще и потому, что она искиючала из товарооборота значительные объемы имущества, а это, в свою очереАь, могло послужить причиной замеАления темпов роста экономики [7, s. 298]. К тому же вакфы становикись заложниками своих уставов. Согласно учредительным договорам, вакф наАлежало использовать строго согласно целям оговоренным при его созАании. Подобное поможение Аел со временем привоАило к функциональной узости вакфов.

ЗАесь в пример можно привести вакфы, созАанные Аля содержания караван-сараев. Караван-сараями на Ближнем и СреАнем Востоке назывались общественные строения, которые Аавали кров и стоянку путешественникам. Как правило, к использованию караван-сараев прибегали торговые караваны. С течением време- ни географические маршруты торговых путей менялись, и это Аелало существование многих караван-сараев бессмысленным и ненужным. В то же время вакфы, если это не было предусмотрено их уставами, не могми изменять направление своей деятемьности, а следовательно, были вынуждены вылелять среАства на содержание тех учрежАений социальной помощи, существование которых уже Аавно утратило свой смысл. В этой связи американский исследователь АэвиА Стефан Паверс (David Stephan Powers) отмечает: «Скорее всего, именно по этой причине «конечной $\gg$ миссией вакфа, которая исчерпывака бы все его уставные цеми, называлась помощь нужАающимся $>[8$, р. 387]. Такое положение Аел касалось не только караван-сараев, но и многих Аругих учрежАений и институтов социальной помощи.

Постепенно такое положение Аем приводило к тому, что количество вакфов, нацеленных исключительно на помощь беАнякам становилось непомерно бомьшим. К примеру, благотворительные столовые в Стамбуле были рассчитаны на ежеАневное обеспечение пропитанием около 30 тысяч человек, что составцяло примерно $10 \%$ от всего населения города [9, р. 475]. Подобная ситуация позволяла критикам говорить о пагубном влиянии вакфов на общее состояние экономики. Существовац и моральный момент: покучая регумярную социамьную помощь, беАняки не имели стимула работать или как-то улучшать свое положение.

Негативно сказывалась на эффективности Аеятельности и общая консервативность вакуфной системы. Особенно это касалось образовательных вакфов, которые на протяжении столетий преподавали школьникам и студентам неизменную учебную программу. Пересмотреть образоватемьные программы в соответствии с насущными потребностями было практически невыполнимо, поскольку возможности какихмибо изменений быми крайне ограничены. ПоАобное положение четко прописывацось в уставе вакфов.

Похожая ситуация существовала и с сельскохозяйственными землями, находившимися во владении вакфов. К примеру, если в уставе было прописано, что на опредеменной земле Аолжна 
выращиваться определенная сельскохозяйственная культура, то изменить это положение со временем уже не преАставлялось возможным, Ааже если выращивание этой кумьтуры было уже неэффективным и ненужным. Российский политолог П.В. ШАыков отмечает: «Все эти особенности превращахи систему вакфов в механизм, главной целью которого было воспроизвоАство и сохранение традиций, «ритуала», а не экономическая продуктивность» $[1$, с. 60].

\section{Часть 3. Поможение вакуфной системы в XX веке}

K началу XX века репутация вакфов была серьезно испорчена. Начали возникать вопросы об оправданности и законности существования вакуфной системы. К тому же в тот период государство уже стремится контролировать систему социальной помощи и благотворительности. Эти тенденции привели в начале XX века к массовой конфискации вакуфного имущества. Конфискации вакуфного имущества производились сначала в Османской империи, а затем, после ее распада, и на ее бывших территориях - в Турции, Египте, Сирии, Паместине и т. А.

Пик кризиса вакуфной системы приходится на начахо постимперского периода. В 1920-е годы к власти в Турции приходят национальные силы во главе с Мустафой Кемалем Ататюрком. 29 октября 1923 года была создана Турецкая республика. В 1924 году принята Конституция турецкой республики. Турция вступика на путь реформ и обновлений. Новая власть взяла курс на создание светского государства [10].

Большинство сторонников социальных преобразований выступали за упразднение вакуфной системы. С их точки зрения, этот институт мешац экономическому развитию страны, поскольку выводим из активного оборота значительный объем земельной и иной собственности. К тому же из-за неэффективного управления эта собственность быстро приходила в негодность.

Вопрос о реформировании вакуфной системы не исчезал с политической повестки Аня. В частности, в заявлении парламента (ВНСТ) от 21 октября 1920 года было отмечено о необхоАимости реформировать вакуфный сектор «в соответствии с нужАами и потребностями нации, а также в Аухе взаимопомощи и братства» $[11$, s. 45$]$. В том же 1920 году бымо создано Министерство по Аелам шариата и вакфов [12, s. 6].

Кемалисты планировали Аецентрализовать управление вакфами. Об этом свидетельствует 11 статья Временной конституции 1921 года, согласно которой, управмение провинциальными вакфами Аолжно было быть передано в ведение губернских советов, то есть, на уровень местной администрации. ОАнако из-за авторитарного характера новой власти этот принцип так никогАа и не выполнялся. Наоборот, вскоре был взял курс на централизацию управления социальноэкономическими институтами.

В резумьтате реформы 3 марта 1924 года Министерство по Аелам шариата и вакфов упразАнялось. Управление вакфов было передано в ведение ГАавного управления вакфов (ГУВ). Согласно закону №429, все вакфы налмежало перевести «в распоряжение нации и использоваться в соответствии с ее нуждами и интересами» $[13$, s. 665$]$. С принятием этого закона начался процесс постепенного установмения государственного контроля наА вакуфной системой. В первую очереАь это относилось к религиозным, культурным и образовательным учреждениям (школы, медресе, библиотеки, мечети). По мнению кемалистов, «непокорный и фаталистический > характер учрежАений, веками кормивших и обеспечивавших кров религиозным служитемям и простым верующим, противоречим сути современного государства.

Новая власть считала необходимым, вопервых, секуляризировать институт вакфов, а во-вторых, поставить его на службу народу и турецкому национализму $[14$, s. 11$]$. Следуя этому принципу многие влиятельные Аеятели того времени учрежАами так называемые «светские» вакфы.

В 1926 году Вемикое национальное собрание Турции принимает составленный по швейцарскому образцу ГражАанский кодекс. Новый кодекс полностью отменял многотомный МеАжемле - свод законов Османской империи, сохранявший многие положения шариата. Таким образом, в Турции были установмены светские принципы семейного и гражАанского права. 


\section{ПОАИТИКА И ОБЩЕСТВО • 6 (138) • 2016}

Принятие нового ГражАанского кодекса привемо к Аальнейшему понижению общественного и правового значения вакуфной системы.

Завершающим шагом в правовом оформлении управления вакфами в тот периоА явикось принятие в 1935 году Закона о вакфах №2762 [1, с. 97]. Тогда же, в 30-е годы XX века, была введена классификация вакфов, которую используют в Турции и по сей день. Вакфы были поделены на «старые» и «новые». Старыми назывались вакфы, Аеятельность которых контролировацась непосреАственно ГАавным управлением вакфов, а также те вакфы, у которых были свои руковоАители (мутавамли).

Что касается «новых вакфов», то они отличались от «старых», главным образом, тем, что создавались и функционировали в соответствии с новым Гражданским кодексом. Они имели собственную администрацию, Аеятельность которой Аишь контролировалась ГУВ «от имени государства» $[1$, с. 97].

Таким образом, можно саелать вывоА, что в период еАиноличного правления Республиканской Народной Партии наблюдается процесс серьезного ослабления всех традиционных основ и институтов в Турции. Не составила искмючения и вакуфная система, которая претерпевала ряА серьезных изменений и в целом утратила свой прежний статус и значимость.

В конце 1940-х годов стал переход к многопартийности. С этого момента в Турции постепенно начинается процесс возрождения религиозных основ общества. Аогично, что оАним из таких традиционных институтов, подлежащих возрожАению, стала и вакуфная система.

В школьную программу были возвращены религиозные Аисциплины, увеличивался бюАжет Министерства по делам религии [15, с. 69]. За счет новых фондов ГАавное управление вакфов за три года осуществимо ремонт 600 мечетей и мавзолеев. С 1950 по 1960 год было открыто или заново введено в строй более 15 тыс. мечетей. Стремительно возрастает количество религиозных организаций: если в 1946 году их было всего 11, то к 1960 году стало 51044 [15, с. 69].

ПравАа, после военного переворота мая 1960 года новая власть предприняла попытки снова установить контроль наА религиозными инсти- тутами. ОАнако по объективным причинам этот контроль не мог быть уже жестким. Те политические силы, которые возникли после введения многопартийности и связывали свою политики с исламом, не только не уходили с политической арены, но и продолжали получать все большую подАержку в обществе.

Следующим значимым моментом в истории вакфов в Турции бымо принятие в 1967 году поправок к Гражданскому кодексу, известных как Закон о вакфах №903 от 13 июля 1967 года [1, с. 160]. Закон был принят поА Аавмением промышменных и финансовых кругов. Поможения закона преАставляли собой сочетание положений шариата и норм, заимствованных из ГражАанского коАекса США. Закон устанавливац формы вакфов, системы их управления и контроля наА ними. $\mathrm{OH}$ серьезно скорректировал принцип «неотменяемости» (невозможности упразднения) вакфов, который был закреплен в мусульманском праве. Теперь вводилась процеАура их миквидации. Аиквидировать вакфы можно было мибо через суА с преАварительного разрешения ГАавного управцения вакфов, Аибо по решению правитемьства в случае, если деятельность вакфа признавамась вредоносной. Была упрощена процедура создания вакфов, расширялся круг возможных вакифов (учредителей), были прописаны цели Амя созАания «новых вакфов». В законе четко прописывались механизм наАзора за вакфами, а также принципы его функционирования. Значительно расширялись возможности финансовоэкономической деятельности вакфов. Теперь им разрешалось создавать коммерческие компании и использовать доходы от коммерческой деятельности на собственные нужды. Разрешалось также организовывать целые сети вакфов, в рамках которых один вакф мог при необходимости передать часть своих среАств Аругому. Наконец, новый закон возвращам в употребление сам термин «вакф».

СлеАующим важным моментов Амя истории вакуфной системы в Турции бым военный переворот сентября 1980 года. На этот раз к власти пришли политические силы, нацеленные на возрожАение традиций и исламских ценностей. ВозрожАение традиций рассматривалось также и в качестве препятствия А^я распространения 
мевой илеологии. В то же время, Конституция, принятая в 1982 году значительно урезала каналы гражАанской активности. Поэтому вакфы снова становились одним из основных инструментов гражданской мобилизации и социализации и экономическим механизмом, который использовался преАставителями различных социальных групп. Помимо непосреАственной благотворительности, вакфы теперь брали на себя функции многочисленных организаций и ассоциаций, которые существовали вплоть Ао 1980 года. Эти организации функционировами в таких общественных сферах, как образование, защита прав человека, защита прав женщин, охрана окружающей среАы, зАравоохранение, поААержание культурных связей и траАиций, пенсионное обеспечение, страхование граждан. Они также оказывали материацьную подАержку исследовательским центрам и спортивным клубам. Помимо всего прочего, вакфы продолжали осуществлять финансирование широкого спектра религиозных организаций. В целом в 80 - 90-е годы наблюдается общая миберамизация законоАательства и благожелательное отношение вмастей к Аальнейшему развитию вакуфной системы. Эти тенденции привоАят к стремительному росту независимых источников финансирования в социацьной сфере, но оАновременно и к резкому увеличению количества так называемых «исламистских вакфов» - вакфов, связанных с суфийскими братствами. Бессрочный характер вакфов обеспечивал религиозным организациям финансовую стабильность. В 80-е годы в связи с процессами миберализации значительное количество таких организаций было преобразовано в вакфы.

Общая социально-экономическая и политическая атмосфера в те годы способствовама росту влияния рекигиозных организаций в обществе. Их позиции становимись все более прочными на фоне обострения ряда социальных проблем: роста безработицы, увеличения уровня беАности, распространения трущоб на окраинах крупных городов. Укреплению позиций религиозных организаций в Турции в те годы способствовац и общий межАународный климат. Еще в конце 1950-х и в 1960-е годы в результате получения рядом африканских колоний незави- симости ПроИсхоАИТ ПОАъеМ исламскоГо АВИЖения в мире. Затем в 1979 году происходит исламская революция в Иране. В свою очередь имело место и Аавление со стороны ЗапаАа, который поднимах вопрос о соблюдении прав человека и свободе совести [1, с. 172$]$.

Начиная с 70-х годов наблюдается явное стремление исламистских организаций ограничить вмешательство государства в их деятельность. Они также стремятся войти во вмастные структуры. В январе 1970 года создается Партия национацьного поряАка - исламистская по своей сути. В этой связи вакфы становятся механизмом построения исламского общества в Турции. Вакфы используются исламистами, главным образом, с целью распространения ремигиозного образования. В эти годы исламисты открывают школы, теологические факультеты, а также курсы по изучению Корана. В тот периоА исламисты внеАряются в государственные структуры как на уровне провинциальных аАминистраций, так и на уровне центрамьной власти.

\section{Часть 4. Развитие турецкой системы вакфов в новейший исторический периоА}

Новейший этап истории вакфов (1990 - 2000 гг.) примечателен появлением в вакуфной системе нового субъекта. Так называемый ТЮСЕВ - аббревиатура по первым буквам официального названия (TÜSEV - Türkiye Üçüncü Sektör Vakfi) [16]. Этот этап знаменателен также и тем, что теперь вакфы становятся, помимо всего прочего, механизмами развития и реализации гражданской активности. Та система регулирования вакфов, которая была сформирована на более ранних этапах истории, хоть и способствована развитию благотворительности в Турции, но, в то же время, препятствоваца развитию гражАанской активности.

ТЮСЕВ также называют вакфами «третьего сектора». ТЮСЕВ объединил в себе организации «секумярного», светского характера. ИАея подобной организации возникла в начале 90-х годов XX века поА влиянием общеевропейского Авижения в подАержку некоммерческих и негосударственных организаций. Центральная заАача состояна в том, чтобы выработать стратегию 
развития Аобровольных ассоциаций и фонАов, Аля которых получение прибыли не является главной цемью. Эти организации главным образом Аолжны были облалать фикантропическими функциями. В итоге в 1993 году по инициативе прогрессивных турецких организаций бым созАан ТЮСЕВ. По своей сути ТЮСЕВ преАставмяет собой федерацию вакфов, объединение благотворительных фондов. За несколько мет это объеАинение смогло привлечь в свои ряАЫ более 700 вакфов [1, с. 197]. ТЮСЕВ был создан по подобию Европейского центра фимантропических фонАов, созАанного в 1989 году с целью развития межАународного партнерства в сфере благотворительности и иной социальной помощи $[1$, с. 197].

Созданию организации способствовало стремление Турции стать членом Европейского союза. ТЮСЕВ обозначах себя как некий Аемократический институт, который будет служить каналом реализации гражАанских инициатив, а также содействовать развитию гражАанского общества и модернизации турецкого социума в целом. ТЮСЕВ бым призван способствовать также развитию сети неправительственных организаций в Турции. Новые политические условия внесли значительные изменения в само содержание института вакфов. В функциональном плане вакфы теперь все более походили на финансовые организации. Реформы системы вакфов в 2000-е годы были направлены на расширение видов их Аеятельности.

По статистике на 2014 год Аеятельность «новый вакфов» включает в себя широкий спектр направмений [17]:

\begin{tabular}{|l|c|}
\hline \multicolumn{1}{|c|}{ Область деятельности вакфов } & Количество \\
\hline Образование & 1957 \\
\hline Социальная помощь & 1268 \\
\hline Здравоохранение & 173 \\
\hline Культура & 138 \\
\hline Защита окружающей среды & 56 \\
\hline Спорт & 42 \\
\hline Наука & 27 \\
\hline Сельское хозяйство и животноводство & 18 \\
\hline В других областях & 326 \\
\hline
\end{tabular}

Таблиияа 1. Yeni vakif istatistikleri 31.12.2014

(Аеятельность, осуществляемая фондами в течение года, особенно та, которая осуществляется в первую очередь, подразделяется на секторы. Так, за 2014 год 1957 фондов первостепенно проводили свою деятельность в секторе образования, а 1253 фонда - в секторе социальной помощуи.)

В 2008 году в Турции принимается закон №5737 «О Аеятельности вакфов». Закон быц нацелен на привлечение к Аеятельности вакфов иностранных благотворитемьных организаций и на расширение географии деятельности вакуфной системы. Он также ставих задачу разработки методов руководства вакфами и механизмов наАзора за их деятельностью.

Новое законодательство вводило более свободный режим управления вакуфными активами и упрощало порядок формирования попечительского совета. Оно также сокращало контроль государства наА вакфами и преАоставцяло им более широкий спектр возможностей Аля их меЖАународной Аеятельности.

Как мы виАим на новейшем этапе истории бым взят курс на привлечение к Аеятельности вакфов иностранных благотворительных организаций. В результате Аействия нового закона институт вакфов еще больше превращался в структуру, близкую по своей сути к межАународным благотворительным фондам. В послеАние годы увеличивается число вакфов, задействованных в межАународной Аеятемьности. В 2010 году их количество составимо 112, в 2014 уже 124 [17].

Новейшая конфигурация вакуфной системы в Турции преАставмяет собой синтез секуАяризованного объеАинения вакфов (ТЮСЕВ) и исламистским вакфов. И те, и Аругие сумеми создать группы Аавмения, которые влияют как на социальные, так и на политические процессы в Турции. На фоне развития неправительственных организаций наблюАается постепенный уход государства из сферы образования, культуры, промышиенности, научных исследований. В то же время возрастает влияние вакфов в этих сферах. Как и в османскую эпоху, вакфы становятся оАной из кмючевых составцяющих турецкого общества.

\section{Выводы}

Таким образом, можно прийти к следующим выводам. В Османской империи вакфы были, пре- 
ЖАе всего моделью социальной помощи через институт исламской рекигии. В периоА социамьных реформ Турции (1950 гоА) начинается постепенное восстановмение вакуфной системы. Качественно новый этап в истории благотворительности в Турции начинается с принятия в 1967 году нового законодательства. Аеятельность вакфов была переведена на рельсы экономической эффективности. В отАельную группу выделялись так называемые «исламистские вакфы», которые явились основным рычагом социального Аействия Аля религиозных организаций. В новейший периоА истории созАается ассоциация ТЮСЕВ, которая становится своего рода ассоциацией секумярного характера. Она объединима в себе нерелигиозные вакфы. В то же время продолжают свое развитие и активную Аеятельность исламистские вакфы, которые осуществляют поААержку и финансирование исламистских Авижений и человеческих ресурсов. Можно отметить, что на современном этапе вакфы (как исламистские, так и секумярные) становятся своего рода рычагами социальной мобимизации. Также с появлением ТЮСЕВ расширяется и межАународная направленность благотворительной Аеятельности в Турции.

В этой ситуации возрожАение и развитие системы вакфов становится крайне актуацьным. Вакфы становятся кмючевой формой гражАанской активности, что как немьзя кучше отвечает потребностям, вытекающим из развития Аемократических процессов в обществе.

\section{БИБАИОГРАФИЯ}

1. Шиыков П. В. Вакфы в Турции: трансформация традиционного института. М.: ИзАательский дом МарАжэни, 2009. С. 45.

2. Беккин Р. И. Институт вакфа в социально-экономической и политической жизни мусульманских стран / Вестник СПбГУ. Сер. 5. 2008. Вып. 3. С. 67.

3. Powers D. S. The Islamic Family Endowment (Waqf)” / Vanderbilt Journal of Transnational Law. Vol. 32 No. 4, October, 1999.

4. Kayhan O. The Economic Efficiency of Imperial Waqfs in the Ottoman Empire // Helsingin Yliopisto (URL: http://www.helsinki.fi/iehc2006/papers3/Orbay121.pdf).

5. Ozturk N.Vakıflar Arşiv Kayıtlarına Göre Niksar Vakıfları. VD, Sayi XXII, Ankara, 1991.

6. Barkan O. L.FatihImareti 1489 - 1490 Yillari Bilancolan // IUIFM, Clit XXIII, Sayi 1 - 2, Istanbul 1963. S. 290.

7. Arsebuk E.Medeni Hukuk. Başlangıç Ve Şahsın Hukuku, C.I. Ankara, 1938. S. 298.

8. Powers D. S. The Malik! Family Endowment: Legal Norms and Social Practices // IJMES, Vol. 25, 1993. P. 387.

9. Huart C. Imaret // Encyclopaedia of Islam, 1st ed., vol. 2. Leiden, 1927, P. 475.

10. Измайлов Р. И. Кемализм и модернизационные процессы в Турции в 20 - 30-е годы ХХ века // Издательский дом MEАИНА (URL: http://www.idmedina.ru/books/materials/turkology/1/turk_izmailov.htm).

11. Ferudun S.Anayasalarve Siyasi Belgeler. Istanbul, 1962. S. 45.

12. Büyük Millet Meclisi Icra Vekilleri’nin Suret-I Intihabina Dair Kunun (3 Sayilive 2/5/1336 (1920) Tarihli) // RG, 7 Şubat 1921 (1337), Sayi I; Dustur, Tertip III, Clit I. Ankara, 1928. S. 6.

13. Şer’iyeve Evkâf Erkâni Harbiye-I Umumiye Vekaletlerinin Ilgasina Dair 3 Mart 1320 / 1924 Tarihlive 429 Sayili Kanun // RG, 06/03/1340 (1924), Sayi 63; Düstur, Tertip III, Clit V. Ankara, 1931. S. 665.

14. Kunter H.B.Türk Vakiflarinin Milliyetçilik Cephesi // VD, Sayi.III, 1956. S. 11.

15. ШАыков П. В.Политическое измерение системной благотворительности в Турции: исламистские фонды как оборотная сторона возрождения вакфов // Вестник молодых ученых «Аомоносов». Вып. 4 / Отв. ред. И. А. Алешковский, А. И. Анареев. М.: Мысль, 2007. С. 69.

16. Duyurular. TÜSEV'den Haberler // TÜSEV - Türkiye Üçüncü Sektör Vakfı. Third Sector Foundation of Turkey (URL: http://www.tusev.org.tr/tr).

17. Yeni Vakif İstatistikleri (31.12.2014) // T.C. Başbakanlık Vakıflar Genel Müdürlügü (URL: http://www.vgm. gov.tr/icerik.aspx?Id=192).

\section{REFERENCES (TRANSLITERATED)}

1. Shlykov P. V. Vakfy v Turtsii: transformatsiya traditsionnogo instituta. M.: Izdatel'skii dom Mardzheni, 2009. S. 45.

2. Bekkin R. I. Institut vakfa v sotsial'no-ekonomicheskoi i politicheskoi zhizni musul'manskikh stran / Vestnik SPbGU. Ser. 5. 2008. Vyp. 3. S. 67. 


\section{ПОАИТИКА И ОБЩЕСТВО • 6 (138) • 2016}

3. Powers D. S. The Islamic Family Endowment (Waqf)" / Vanderbilt Journal of Transnational Law. Vol. 32 No. 4, October, 1999.

4. Kayhan O. The Economic Efficiency of Imperial Waqfs in the Ottoman Empire // Helsingin Yliopisto (URL: http://www.helsinki.fi/iehc2006/papers3/Orbay121.pdf).

5. Ozturk N.Vakıflar Arşiv Kayıtlarına Göre Niksar Vakıfları. VD, Sayi XXII, Ankara, 1991.

6. Barkan O. L.FatihImareti 1489 - 1490 Yillari Bilancolan // IUIFM, Clit XXIII, Sayi 1 - 2, Istanbul 1963. S. 290.

7. Arsebuk E.Medeni Hukuk. Başlangıç Ve Şahsın Hukuku, C.I. Ankara, 1938. S. 298.

8. Powers D. S. The Malik! Family Endowment: Legal Norms and Social Practices // IJMES, Vol. 25, 1993. P. 387.

9. Huart C. Imaret // Encyclopaedia of Islam, 1st ed., vol. 2. Leiden, 1927, P. 475.

10. Izmailov R. I. Kemalizm i modernizatsionnye protsessy v Turtsii v 20 - 30-e gody KhKh veka // Izdatel'skii dom MEDINA (URL: http://www.idmedina.ru/books/materials/turkology/1/turk_izmailov.htm).

11. Ferudun S.Anayasalarve Siyasi Belgeler. Istanbul, 1962. S. 45.

12. Büyük Millet Meclisi Icra Vekilleri'nin Suret-I Intihabina Dair Kunun (3 Sayilive 2/5/1336 (1920) Tarihli) // RG, 7 Şubat 1921 (1337), Sayi I; Dustur, Tertip III, Clit I. Ankara, 1928. S. 6.

13. Şer'iyeve Evkâf Erkâni Harbiye-I Umumiye Vekaletlerinin Ilgasina Dair 3 Mart 1320 / 1924 Tarihlive 429 Sayili Kanun // RG, 06/03/1340 (1924), Sayi 63; Düstur, Tertip III, Clit V. Ankara, 1931. S. 665.

14. Kunter H.B.Türk Vakiflarinin Milliyetçilik Cephesi // VD, Sayi.III, 1956. S. 11.

15. Shlykov P. V.Politicheskoe izmerenie sistemnoi blagotvoritel'nosti $v$ Turtsii: islamistskie fondy kak oborotnaya storona vozrozhdeniya vakfov // Vestnik molodykh uchenykh «Lomonosov».Vyp.4 / Otv. red. I. A. Aleshkovskii, A. I. Andreev. M.: Mysl', 2007. S. 69.

16. Duyurular. TÜSEV'den Haberler // TÜSEV - Türkiye Üçüncü Sektör Vakfi. Third Sector Foundation of Turkey (URL: http://www.tusev.org.tr/tr).

17. Yeni Vakif İstatistikleri (31.12.2014) // T.C. Başbakanlık Vakıflar Genel Müdürlüğ̈̈ (URL: http://www.vgm. gov.tr/icerik.aspx?Id=192). 